Vol 10, Issue 12, 2017

\title{
INVESTIGATION THE ASSOCIATION BETWEEN MTHFR GENE POLYMORPHISM AND HOMOCYSTEINE IN IRANIAN PREGNANT WOMEN
}

\author{
ELHAM SADAT SONBOLESTAN, HOSSEIN SAZGAR*, NOOSHA ZIA-JAHROMI, FARZANEH MOHAMADI FARSANI
}

${ }^{1}$ Department of Biology, Faculty of Sciences, Shahrekord Branch, Islamic Azad University, Shahrekord, Iran. Email: Hoseinsazgar@yahoo.com Received: 01 June 2017, Revised and Accepted: 01 September 2017

ABSTRACT

Objective: This study was aimed to investigate the association between polymorphisms in MTHFR gene and Vitamin B12-dependent homocysteine metabolism.

Methods: Hyperhomocysteinemia has been implicated as a risk factor for complications in pregnancy including abortion, preeclampsia, and placental abruption. Several epidemiological studies have investigated the associations of MTHFR C677T polymorphism with hypertension or hypertension in pregnancy. However, the results were controversial. Numbers of 100 samples from healthy pregnant women as control criteria and 100 samples from fertile women have been collected. Due to research on MTHFR polymorphism, special primers have been designed. The research on MTHFR polymorphism has been done by restriction fragment length polymorphism assay.

Results: The results demonstrated $9.26 \%$ have been registered for heterozygous individuals and the homocysteine level of homozygous individuals was $41.18 \%$ (higher than the normal level). The results showed a significant difference in the homocysteine levels of homozygous individuals and the homocysteine levels of healthy individuals $(\mathrm{p}=0.004)$. Furthermore, there was no significant difference in the homocysteine levels of heterozygous individuals and the homocysteine levels of healthy individuals ( $\mathrm{p}=0.34)$. Similarly, a significant difference in the B12 levels in blood of homozygous individuals and the homocysteine levels of healthy individuals have been showed $(\mathrm{p}=0.00)$.

Conclusion: The mutation of gene MTHFR C677T causes an increase of the homocysteine level, decrease of the level of folic acid and B12 vitamin in heterozygous individuals but a relationship among homocysteine level, the level of folic acid and B12 vitamin not found.

Keywords: B12 vitamin, Folic acid, Homocysteine level, Infertility, MTHFR C677T.

(C) 2017 The Authors. Published by Innovare Academic Sciences Pvt Ltd. This is an open access article under the CC BY license (http://creativecommons. org/licenses/by/4. 0/) DOI: http://dx.doi.org/10.22159/ajpcr.2017.v11i1.21579

\section{INTRODUCTION}

Homocysteine (tHcy) is a sulfur-containing intermediate in metabolism of methionine, which can be catabolized in the pathway of transsulfuration (Vitamin B6-dependent) [1]. In humans, two main factors affect tHcy concentration: Polymorphism in genes which encode enzymes or transport proteins involved in the Vitamin B12-dependent homocysteine metabolism and diet, especially the intake of folate and Vitamin B12 [2].

MTHFR (C677T), MTR (A2756G), and MTRR (A66G) polymorphisms genes have been associated with high tHcy concentrations in some populations [3]. The human MTHFR (methylenetetrahydrofolate reductase) gene has been localized to chromosome $1 \mathrm{p} 36.3$ and is compound of 11 exons [4]. The C677T thermolabile polymorphism in the gene encoding 5,10-MTHFR has consistently been associated with plasma tHcy levels. $\mathrm{C}$ to $\mathrm{T}$ substitution at the nucleotide 677 , a point mutation, in the coding sequence of the MTHFR gene is the most general enzyme defect associated with moderately-raised homocysteine concentrations [5]. The MTHFR gene polymorphisms are commonly associated with hyperhomocysteinemia. The best characterized MTHFR gene polymorphism inclusive a transition of $677 \mathrm{C}$ to $\mathrm{T}$, which results in an alanine to valine substitution in forestall catalytic domain of the enzyme. This is a risk factor for neural tube defects and recurrent embryo loss in pregnant women [6].

Enzymes involved in the homocysteine remethylation pathway might act as predisposing factors contributing to NTDs. The C677T polymorphism in the MTHFR gene has been associated with decrease enzyme activity and increased tHcy levels [7] and NTDs risk [8]. The polymorphism of MTHFR A1298C does not alter plasma tHcy concentrations, although subjects with heterozygous genotypes for MTHFR C677T and MTHFR A1298C polymorphisms may be at the risk of mild elevation of tHcy levels [9]. The mentioned polymorphisms were also associated with increased risk of spontaneous abortion [10].

Other enzymes like methionine synthase play an important role in homocysteine metabolism too; and its activity reduction because of inadequate cofactor (Vitamin B12) concentrations may resultin elevated homocysteine levels or A2756G polymorphism [11]. On the other hand, the cystathionine beta-synthase (CBS) catalyzes the condensation of serine and homocysteine to form cystationine, and abnormality in CBS activity is manifested in two clinical conditions: Hyperhomocysteinemia and homocystinuria [12]. Several complications in pregnancy have been attributed to hyperhomocysteinemia such as neural tube defects, preeclampsia, and recurrent pregnancy loss [13].

Several studies have compared the association between the MTHFR polymorphism, the Vitamin B status in pregnant women with pregnancy complications, and plasma homocysteine levels. However, some studies have been reported on these relations and homocysteine metabolism with uncomplicated pregnancies in normal women [14].

The aim of this study was to report on our investigation on the effect of the interaction between the C677T MTHFR polymorphism on the homocysteine concentration in normal Iranian pregnant women using restriction fragment length polymorphism (RFLP) method.

\section{METHODS}

Subjects A total of 100 consecutive Iranian pregnant women with at least one abortion in their 24-28 weeks of gestation participated in this 
study. In addition, 100 fertile women were selected as the control group between August 2016 and March 2016. All samples were collected from Beheshti Hospital and Isfahan Infertility Center. The criteria for normal pregnancy are as follows: No pregnancy complications, no medications, and free of pregravid chronic diseases.

\section{Homocysteine estimation}

The quantitative assessment of homocysteine was done using kit which was based on an enzymatic reaction which involves the principle of adsorption with the decrease in absorbance value of the sample at $340 \mathrm{~nm}$ due to oxidation of NADH to NAD+. The estimated values of homocysteine are directly proportional to the quantity of NADH oxidized. Value of homocysteine level in serum above $15 \mu \mathrm{mol} / \mathrm{L}$ was used to define hyperhomocysteinemia.

\section{MTHFR mutation analysis}

DNA was extracted from the whole blood using a Genomic DNA blood kit (SinaClon, Iran) and stored at $-20^{\circ} \mathrm{C}$ for analysis. DNA fragments were amplified from the genomic DNA through the polymerase chain reaction (PCR). Primers are given in Table 1 accompanied with product values. Amplification was carried out in the PCR buffer with $0.5 \mathrm{U}$ Taq DNA polymerase (Fermentas, Germany). PCR conditions comprised an initial denaturation step at $95^{\circ} \mathrm{C}$ for $4 \mathrm{~min}$, followed by 30 cycles of $95^{\circ} \mathrm{C}$ for $40 \mathrm{~s}, 62^{\circ} \mathrm{C}$ for $30 \mathrm{~s}$, and $72^{\circ} \mathrm{C}$ for $30 \mathrm{~s}$, and a final extension step at $72^{\circ} \mathrm{C}$ for $4 \mathrm{~min}$. The PCR product was digested using Hinfl (Takara Shuzo Co., Shiga, Japan). The $\mathrm{C}$ to $\mathrm{T}$ substitution at nucleotide 677 creates an extra HinFI restriction site that cleaves the original 210 bp PCR fragment into $173 \mathrm{bp}$ and $37 \mathrm{bp}$ fragments. Size fractionation of the PCR products was electrophoresis on $2 \%$ agarose gel containing $0.5 \mathrm{mg} / \mathrm{ml}$ ethidium bromide and was visualized using the ultraviolet light.

\section{Statistical analysis}

Data were presented as mean \pm standard deviation (SD) and percentages. All data of serum measures were log transformed to normalize their distributions and were presented as geometric mean \pm SD. After the ANOVA, Duncan's multiple range tests were performed to determine the significance of the differences in the means of serum vitamins and homocysteine among pregnant women with different genotypes of the MTHFR gene. We performed two-way ANOVA to test for differences between genotypes and interactions between genotype and vitamin levels. Multiple regression analysis was used to examine the associations between serum homocysteine and other variables and identify the best predictor among variables. The differences were considered significant at the $5 \%$ level in this study. The SPSS software v24.0 was used in the statistical analyses.

\section{Ethical standards}

The study was approved by the Human Ethics Committee of Islamic Azad University of Shahrekord Branch. The protocol and procedures presented in the project are in accordance with the ethical standards of the responsible committee on human subjects and the Helsinki Declaration of 1964, as revised in 2008

\section{RESULTS}

In total, 100 pregnant women with history abortion and 100 fertile pregnant women as control group were included in genetic analyses. RFLP were used for analysis sequence polymorphisms of proliferated DNA. The PCR product from the second step digested for $4 \mathrm{~h}$ at $37^{\circ} \mathrm{C}$ with HinFI restriction enzyme for C677T MTHFR polymorphism, according to the manufacturer's instructions. The results of enzymatic digestion were identified in a 3\% agarose gel by electrophoresis and ethidium bromide staining. Molecular weight 100bp plus marker (Fermentas, Germany) and undigested PCR products were included in each analysis. The genotypes were deduced from the fragmentation patterns of the amplified DNA which observed in ultraviolet doc gel documentation systems (Fig. 1)

Mean homocysteine levels were higher in women with TT genotype $(29 \mu \mathrm{mol} / \mathrm{l})$ as compared to other genotypes. Mean plasma homocysteine, B12 vitamin and folic acid levels have been shown in Table 2. The results demonstrated $9.26 \%$ have been registered for heterozygous individuals and the homocysteine level of homozygous individuals was 41.18\% (higher than the normal level). The results show a significant difference in the homocysteine levels of homozygous individuals and the homocysteine levels of healthy individuals $(\mathrm{p}=0.004)$. Furthermore, there was no significant difference in the homocysteine levels of heterozygous individuals and the homocysteine levels of healthy individuals $(\mathrm{p}=0.34)$. Similarly, a significant difference in the B12 levels in blood of homozygous individuals and the homocysteine levels of healthy individuals have been showed ( $\mathrm{p}=0.00)$. The SNP of C677T MTHFR was successfully genotyped in 100 cases and 100 controls. All the observed genotype frequencies were under the Hardy-Weinberg equilibrium.

\section{DISCUSSION}

The information that the homozygous for C677T transition in the MTHFR gene is related to the fast increment of plasma tHcy is well known [15]. This could be because of lack of vitamin deficiency in both groups. Although the C677T thermolabile variant of the MTHFR is an important genetic tHcy metabolism determinant. Individuals are homozygous for the mutant $\mathrm{T}$ allele exhibit increase elevations of the amino acid in their blood in comparison with other genotypes only under conditions of lower folate status $[16,17]$. This shows that B-vitamin status modifies the relation between the tHcy serum levels and MTHFR C677T mutation. However [17], in a cross-sectional study, the folate-dependent relation between the plasma tHcy concentration and MTHFR C677T genotype by gender was examined, which showed the MTHFR genotype is not a strong predictor of tHcy levels under diverse conditions of folate status among young women. This data were not confirmed among men [18].

Several studies indicated a positive correlation between pregnancy complications and homocysteine levels. It has been found that elevated levels of circulating homocysteine are a risk factor for vascular disease and endothelial dysfunction. Sorensen et al. found that second-trimester elevation of homocysteine was related to 3.2-fold increased risk of preeclampsia [19]. Acilmis et al. concluded that maternal and fetal

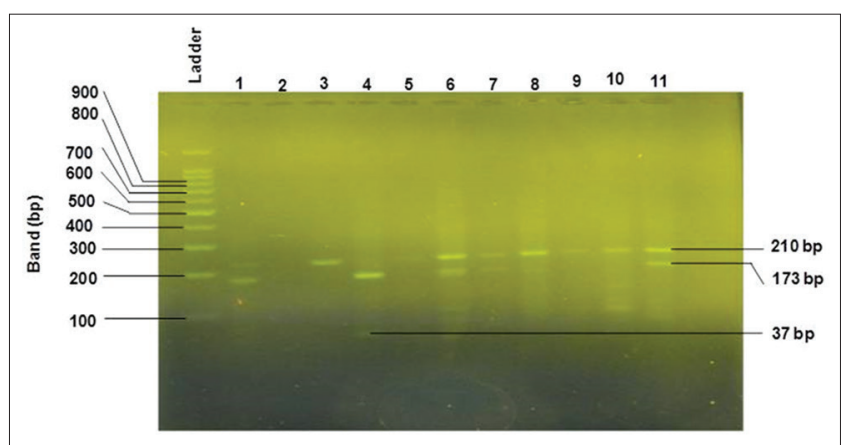

Fig. 1: Gel showing the analysis of amplified product of MTHFR gene on $3 \%$ agarose gel. Ladder $100 \mathrm{bp}$ was run on $3 \%$ agarose gel

Table 1: PCR and RFLP procedures and products of MTHFR C677T gene

\begin{tabular}{llll}
\hline Primers name & Primer sequence (5' to $\mathbf{3}^{\prime}$ ) & Restriction enzyme & Annealing temp ( $\left.{ }^{\circ} \mathbf{C}\right)$ \\
\hline MTHFR-F & AGC TTT GAG GCT GAC CTG AAG & HinFI & 62 \\
MTHFR-R & AGG ACG GTG CGG TGA GAG TG & & 120 \\
\hline
\end{tabular}

RFLP: Restriction fragment length polymorphism, PCR: Polymerase chain reaction 
Table 2: The number and frequency of homocysteine, folic acid and B12 vitamin

\begin{tabular}{llll}
\hline Samples & $\begin{array}{l}\text { Homocysteine } \\
(\boldsymbol{\mu m o l} / \mathbf{L})\end{array}$ & $\begin{array}{l}\text { Folic acid } \\
(\mathbf{n g} / \mathbf{m L})\end{array}$ & $\begin{array}{l}\text { B12 vitamin } \\
(\mathbf{n g} / \mathbf{m L})\end{array}$ \\
\hline Homozygous & 29 & 4.5 & 190 \\
Heterozygous & 28 & 4.2 & 170 \\
Healthy & 7 & 11.7 & 439.5 \\
\hline
\end{tabular}

serum homocysteine levels were found to be significantly higher in severe preeclampsia group compared to control groups suggesting and mild preeclampsia that elevated serum levels of homocysteine might be associated with severity of preeclampsia [20].

In a study in 1999 Christensen et al. reported an increased risk of having an NTD case when MTHFR 677TT genotype was associated with red blood cell folate. Genotype of MTHFR 677TT and lower levels of plasma folate were also associated with DNA methylation reduction [21]. Moreover, hypomethylation in DNA was associated with MTHFR 1298AA genotype and reduced folate levels [22]. However, 677TT genotype high prevalence within the 1298AA group (79\%) and similar biochemical features of 1298AA/677CC and 1298CC/677CC haplotypes suggest that the gene-nutrient interaction affecting DNA methylation in 1298AA is mainly because of the coexistence of 677TT genotype [23].

Previous studies had demonstrated a higher frequency of homozygous to the genotype of MTHFR C677T and higher tHcy serum levels in women with recurrent miscarriage than in healthy groups [24]. However, Creus et al. and Pihusch et al. did not demonstrate such association $[25,26]$. In another study, the frequency of genetic polymorphisms that encode enzymes involved in folate- and Vitamin B12-dependent homocysteine metabolism, the MTHFR C677T and A1298C; MS A2756G and CBS 844 ins68 insertion, did not show differences in a group of women with recurrent miscarriage and a healthy group. This is in agreement with Zonouzi et al. and Puri et al. studies that investigated the MTHFR polymorphisms in the North of Iran and India, respectively [27,28]. In contrast, other studies described the relationship between the gene polymorphisms: MTHFR4; MS and recurrent abortion [29]. Murphy et al. in 2004 reported that elevated total plasma homocysteine during pregnancy has been associated with adverse pregnancy outcomes [30]. Bergen et al. concluded that higher homocysteine concentration in early pregnancy has higher risk of adverse pregnancy outcome [31,32]. Refsum reported that women having high homocysteine levels are at increased risk of pregnancy complications and adverse pregnancy outcome [33,34]. Mtiraoui et al. in Tunisia also analyzed female patients with RPL and control women using PCRRFLP analysis. The frequency of the A1298C SNP CC genotypes was significantly more in the patients group. A comparable frequency of double heterozygosity $(1298 \mathrm{~A} / \mathrm{C}$ and $677 \mathrm{C} / \mathrm{T})$ had seen in 14 patients versus 5 healthy subjects $(\mathrm{p}=0.10)$ [35]. In Austria, 145 women with a history of three or more consecutive pregnancy losses before 20 weeks' gestation and 101 control postmenopausal women with at least 2 live births and no history of pregnancy loss were collected. The results indicated that genotype frequencies and allele of single MTHFR (MTHFR A1298C, MTHFR C677T) polymorphisms were not significantly different in patients and the healthy groups [36].

\section{CONCLUSION}

Despite the fact that significant difference in mean homocysteine levels in women with pregnancy complications and those without pregnancy complications has been seen in various studies, it is still not known if there is a cutoff value that could predict pregnancy complications with adequate accuracy. The mutation of gene MTHFR C677T causes increase of the homocysteine level, decrease of the level of folic acid and B12 vitamin in heterozygous individuals but a relationship among homocysteine level. It is suggested that a larger trial be undertaken in India as there is a high prevalence of hyperhomocysteinemia to understand its causes and any association with pregnancy complications

\section{ACKNOWLEDGMENT}

The authors would like to thank all the staff members of the Isfahan University and Biotechnology Research Center of Islamic Azad University of Shahrekord Branch in Iran, for their sincere support.

\section{REFERENCES}

1. Milman N, Byg KE, Hvas AM, Bergholt T, Eriksen L. Erythrocyte folate, plasma folate and plasma homocysteine during normal pregnancy and postpartum: A longitudinal study comprising 404 Danish women. Eur J Haematol 2006;76:200-5.

2. Cao Y, Xu J, Zhang Z, Huang X, Zhang A, Wang J, et al. Association study between methylenetetrahydrofolate reductase polymorphisms and unexplained recurrent pregnancy loss: A meta-analysis. Gene 2013;514:105-11.

3. Aléssio AC, Annichino-Bizzacchi JM, Bydlowski SP, Eberlin MN, Vellasco AP, Höehr NF. Polymorphisms in the methylenetetrahydrofolate reductase and methionine synthase reductase genes and homocysteine levels in Brazilian children. Am J Med Genet A 2004;128A:256-60.

4. Al-Meman AA, Ismail R, Musa N, Mohamad N. Simultaneous detection of multiple polymorphisms in Cyp2b6 and Opmr1 by nested pcr: A good approach for patients on methadone. Int J Pharm Pharm Sci 2014;6(3):215-22

5. Spiroski I, Kedev S, Antov S, Arsov T, Krstevska M, Dzhekova-Stojkova S, et al. Methylenetetrahydrofolate reductase (MTHFR-677 and MTHFR-1298) genotypes and haplotypes and plasma homocysteine levels in patients with occlusive artery disease and deep venous thrombosis. Acta Biochim Pol 2008;55:587-94.

6. Jacques PF, Bostom AG, Williams RR, Ellison RC, Eckfeldt JH, Rosenberg IH, et al. Relation between folate status, a common mutation in methylenetetrahydrofolate reductase, and plasma homocysteine concentrations. Circulation 1996;93:7-9.

7. Blom HJ, Shaw GM, den Heijer M, Finnell RH. Neural tube defects and folate: Case far from closed. Nat Rev Neurosci 2006;7:724-31.

8. Frosst P, Blom HJ, Milos R, Gyette P, Sheppard CA, Matthews RG, et al. A candidate genetic risk factor for vascular disease: A common mutation in methylenetetrahydrofolate reductase (MTHFR). Nat Genet 1995; 10:111-3

9. Cunha AL, Hirata MH, Kim CA, Guerra-Shinohara EM, Nonoyama K, Hirata RD. Metabolic effects of C677T and A1298C mutations at the MTHFR gene in Brazilian children with neural tube defects. Clin Chim Acta 2002;318:139-43.

10. Van der Put NM, Gabreels F, Stevens EM, Smeitink JA, Trijbels FJ, Eskes TK, et al. A second common mutation in the methylenetetrahydrofolate reductase gene: An additional risk factor for neural tube defects? Am J Hum Genet 1995;62:1044-51.

11. Zetterberg H. Methylenetetrahydrofolate reductase and transcobalamin genetic polymorphisms in human spontaneous abortion: Biological and clinical implications. Reprod Biol Endocrinol 2004;2:7.

12. Barbosa PR, Stabler SP, Machado AL, Braga RC, Hirata RD, Hirata $\mathrm{MH}$, et al. Association between decreased vitamin levels and MTHFR, MTR and MTRR gene polymorphisms as determinants for elevated total homocysteine concentrations in pregnant women. Eur J Clin Nutr 2008;62:1010-21.

13. Dutta S, Sinha S, Chattopadhyay A, Gangopadhyay PK, Mukhopadhyay J, Singh $\mathrm{M}$, et al. Cystathionine beta-synthase T833C/844INS68 polymorphism: A family-based study on mentally retarded children. Behav Brain Funct 2005;1:25.

14. Puri M, Kaur L, Walia GK, Mukhopadhhyay R, Sachdeva MP, Trivedi SS, et al. MTHFR C677T polymorphism, folate, vitamin B12 and homocysteine in recurrent pregnancy losses: A case control study among North Indian women. J Perinat Med 2013;41:549-54.

15. Ghaffari K, Ghasemi A, Ghotaslou A, Mohammadi M, Salmanpour Z. Study of correlation between C677T and A1298C mutations on the MTHFR gene with plasma homocysteine levels and venous thrombosis in pregnant women at risk of thrombosis. Zahedan J Res Med Sci 2015;17:29-34.

16. Nair RR, Khanna A, Singh R, Singh K. Association of maternal and fetal MTHFR A1298C polymorphism with the risk of pregnancy loss: A study of an Indian population and a meta-analysis. Fertil Steril 
2013;99:1311-8.

17. Creus M, Deulofeu R, Peñarrubia J, Carmona F, Balasch J. Plasma homocysteine and vitamin B12 serum levels, red blood cell folate concentrations, C677T methylenetetrahydrofolate reductase gene mutation and risk of recurrent miscarriage: A case-control study in Spain. Clin Chem Lab Med 2013;51:693-9.

18. Papoutsakis C, Yiannakouris N, Manios Y, Papaconstantinou E, Magkos F, Schulpis KH, et al. The effect of MTHFR(C677T) genotype on plasma homocysteine concentrations in healthy children is influenced by gender. Eur J Clin Nutr 2006;60:155-62.

19. Boas WV, Gonçalves RO, Costa OL, Goncalves MS. Metabolism and gene polymorphisms of the folate pathway in Brazilian women with history of recurrent abortion. Rev Bras Ginecol Obstet 2015;37:71-6.

20. Sorensen TK, Malinow MR, Williams MA, King IB, Luthy DA. Elevated second trimester serum homocysteine levels and subsequent risk of preeclampsia. Gynecol Obstet Invest 1999;48:98-103.

21. Acilmis YG, Dikensoy E, Kutlar AI, Balat O, Cebesoy FB, Ozturk E, et al. Homocysteine, folic acid and vitamin B12 levels in maternal and umbilical cord plasma and homocysteine levels in placenta in pregnant women with pre-eclampsia. J Obstet Gynaecol Res 2011;37:45-50.

22. Friso S, Choi SW, Girelli D, Mason JB, Dolnikowski GG, Bagley PJ, et al. A common mutation in the 5,10-methylenetetrahydrofolate reductase gene affects genomic DNA methylation through an interaction with folate status. Proc Natl Acad Sci USA 2002;99:5606-11.

23. Friso S, Girelli D, Trabetti E, Olivieri O, Guarini P, Pignatti PF, et al. The MTHFR 1298A4C polymorphism and genomic DNA methylation in human lymphocytes. Cancer Epidemiol Biomarkers Prev 2005;14:938-43.

24. Oliveira KC, Bianco B, Verreschi IT, Guedes AD, Galera BB, Galera MF, et al. Prevalence of the polymorphism MTHFR A1298C and not MTHFR C677T is related to chromosomal aneuploidy in Brazilian Turner Syndrome patients. Arq Bras Endocrinol Metabol 2008;52:1374-81.

25. Kim NK, Choi YK, Kang MS, Choi DH, Cha SH, An MO, et al. Influence of combined methylenetetrahydrofolate reductase (MTHFR) and thymidylate synthase enhancer region (TSER) polymorphisms to plasma homocysteine levels in Korean patients with recurrent spontaneous abortion. Thromb Res 2006;117:653-8.
26. Robertson L, Wu O, Langhorne P, Twaddle S, Clark P, Lowe GD, et al. Thrombophilia in pregnancy: A systematic review. Br J Haematol 2005;132:171-96.

27. Pihusch R, Buchholz T, Lohse P, Rübsamen H, Rogenhofer N, Hasbargen $\mathrm{U}$, et al. Thrombophilic gene mutations and recurrent spontaneous abortion: Prothrombin mutation increases the risk in the first trimester. Am J Reprod Immunol 2001;46:124-31.

28. Zonouzi AP, Chaparzadeh N, Estiar MA, Sadaghiani MM, Farzadi L, Ghasemzadeh A, et al. Methylenetetrahydrofolate reductase C677T and A1298C mutations in women with recurrent spontaneous abortions in the Northwest of Iran. ISRN Obstet Gynecol 2012;2012:945486.

29. Klai S, Fekih-Mrissa N, El Housaini S, Kaabechi N, Nsiri B, Rachdi R, et al. Association of MTHFR A1298C polymorphism (but not of MTHFR C677T) with elevated homocysteine levels and placental vasculopathies. Blood Coagul Fibrinolysis 2011;22:374-8.

30. Kim JH, Jeon YJ, Lee BE, Kang H, Shin JE, Choi DH, et al. Association of methionine synthase and thymidylate synthase genetic polymorphisms with idiopathic recurrent pregnancy loss. Fertil Steril 2013;99:1674-80.

31. Murphy MM, Scott JM, Arija V, Molloy AM, Fernandez-Ballart JD. Maternal homocysteine before conception and throughout pregnancy predicts fetal homocysteine and birth weight. Clin Chem 2004;50:1406-12.

32. Singh S, Raguvaran R, Rajkumar K. Factors Influencing Prostate Cancer Review Article, Int J Pharm Pharm Sci, Vol 6, Issue 6, 33-35.

33. Bergen NE, Jaddoe VW, Timmermans S, Hofman A, Lindemans J, Russcher $\mathrm{H}$, et al. Homocysteine and folate concentrations in early pregnancy and the risk of adverse pregnancy outcomes: The Generation R Study. BJOG 2012;119:739-51.

34. Refsum H. Folate, vitamin B12 and homocysteine in relation to birth defects and pregnancy outcome. Br J Nutr 2001;85 Suppl 2:S109-13.

35. Mtiraoui N, Zammiti W, Ghazouani L, Braham NJ, Saidi S, Finan RR, et al. Methylenetetrahydrofolate reductase C677T and A1298C polymorphism and changes in homocysteine concentrations in women with idiopathic recurrent pregnancy losses. Reproduction 2006;131:395-401.

36. Hohlagschwandtner M, Unfried G, Heinze G, Huber JC, Nagele F, Tempfer C. Combined thrombophilic polymorphisms in women with idiopathic recurrent miscarriage. Fertil Steril 2003;79:1141-8. 